\title{
Expectations and limitations of ovarian tissue transplantation
}

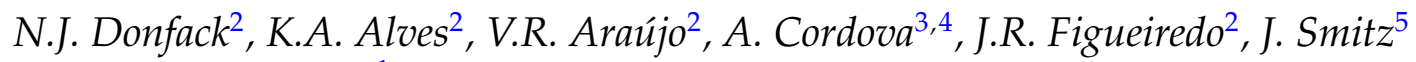 \\ and A.P.R. Rodrigues ${ }^{1}$
}

Faculty of Veterinary Medicine, LAMOFOPA, State University of Ceará, Fortaleza, Brazil; Department of Biomedical Sciences, Ontario Veterinary College, University of Guelph, Canada; Reproductive Physiology, Toronto Zoo, Canada; and Follicle Biology Laboratory, Center for Reproductive Medicine, Brussels, Belgium

Date submitted: 24.08.2016. Date revised: 16.12.2016. Date accepted: 18.05.2017

\section{Summary}

Constant progress in the diagnosis and treatment of cancer disease has increased the number and prognosis of cancer survivors. However, the toxic effects of chemotherapy and radiotherapy on ovarian function have resulted in premature ovarian failure. Patients are, therefore, still expecting methods to be developed to preserve their fertility successfully. Several potential options are available to preserve fertility in patients who face premature ovarian failure, including immature or mature oocyte and embryo cryopreservation. However, for children or prepubertal women needing immediate chemotherapy, cryopreservation of ovarian tissue is the only alternative. The ultimate aim of this strategy is to implant ovarian tissue into the pelvic cavity (orthotopic site) or in a heterotopic site once oncological treatment is completed and the patient is disease free. Transplantation of ovarian tissue with sufficiently large numbers of follicles could potentially restore endocrine function and allow multiple cycles for conception. However, the success of ovarian tissue transplantation still has multiple challenges, such as the low number of follicles in the graft that may affect their longevity as well as the survival of the tissue during ex vivo processing and subsequent transplantation. Therefore, this review aims to summarize the achievements of ovary grafting and the potential techniques that have been developed to improve ovarian graft survival.

Keywords: Cryopreservation, Fertility preservation, Neovascularization, Oncofertility, Transplantation

\section{Introduction}

Advances in oncological diagnosis and treatments have provided a considerable increase in survival of cancer patients (Jemal et al., 2012), however, chemo-

\footnotetext{
${ }^{1}$ All correspondence to: A.P.R. Rodrigues. Programa de Pós-Graduação em Ciências Veterinárias (PPGCV). Laboratório de Manipulação de Oócitos e Folículos Pré-Antrais (LAMOFOPA). Universidade Estadual do Ceará (UECE). Av. Paranjana, 1700, Campus do Itaperi. Fortaleza - CE - Brasil. CEP: 60740 903. Tel: +55 853101 9852. Fax: +55 8531019840. E-mail: aprrodriguespapers@gmail.com

${ }^{2}$ Faculty of Veterinary Medicine, Laboratory of Manipulation of Oocytes and Preantral Follicles (LAMOFOPA), State University of Ceará, Fortaleza, CE, Brazil.

${ }^{3}$ Department of Biomedical Sciences, Ontario Veterinary College, University of Guelph, 50 Stone Road, Guelph, ON N1G 2W1, Canada.

${ }^{4}$ Reproductive Physiology, Toronto Zoo, 361A Old Finch Avenue, Toronto, Ontario, M1B 5K7, Canada.

${ }^{5}$ Follicle Biology Laboratory, Center for Reproductive Medicine, UZ Brussel, Laarbeeklaan 101, B-1090 Brussels, Belgium.
}

therapy and/or radiotherapy treatments, including alkylating agents may compromise their future fertility (Anderson \& Wallace, 2013). Furthermore, as the number of young cancer survivors augments, the demand for fertility preservation before cancer therapy increases progressively (Donnez et al., 2006b). Cryopreservation and transplantation are, therefore, the main and most viable options to preserve and thus regenerate the fertility of women who will undergo cancer treatment (Donnez et al., 2013).

Especially for children or young patients, the available option to preserve fertility is the cryopreservation of ovarian tissue (slices/fragments) that allows the storage of a large number of primordial and primary follicles (Meirow et al., 2007) and can ensure the restoration of the ovarian endocrine function (Donnez et al., 2013). The cryopreserved ovarian tissue needs, therefore, to be grafted to the patient after a period of storage at low temperatures.

More than a half century ago, a study conducted in mice described the first birth after a whole ovary orthotopic transplantation with previous cryopreservation 
(Parrot, 1960). In humans, the first birth obtained using ovarian tissue cryopreservation and grafting was reported by Donnez et al. (2004) and was a landmark in human reproductive medicine. Since then, the birth of 70 healthy babies (Silber, 2016) has been reported after transplantation of cryopreserved ovarian tissue. Despite these encouraging results, the techniques of cryopreservation and ovarian transplantation to restore reproductive function in women are still considered experimental. New studies are therefore being performed around the world to investigate the best way to restore fertility, either in humans (Burmeister et al., 2013), non-human primates (Amorim et al., 2013), in domestic animals (Fassbender et al., 2007) or in laboratory animals (César et al., 2015).

The natural plasticity of the ovary facilitates grafting to different sites in which they can be revascularized and rapidly restore its normal physiology. Furthermore, ovarian tissue can be transplanted orthotopically to the pelvis (Demeestere et al., 2010) or heterotopically in subcutaneous areas, kidney capsule or fat pad (Youm et al., 2015) as well as in other sites (the rectus muscle: Kim et al., 2009; subperitoneal tissue: Stern et al., 2011). Regardless of the site, the ovarian graft can undergo ischemia and potentially follicular atresia that represent a challenge to the success of this technique. It is necessary, therefore, to make sure that there is good cell communication between graft and host tissue when the ovary is grafted.

The practice of cryostorage followed by transplantation has been restoring fertility and hormone production (in humans: Silber, 2016; and others species: Amorim et al., 2013; Campbell et al., 2014). This option is elective for patients who have high risk of premature ovarian failure (POF) in which oncologists and physicians work together to achieve the patient's global well-being (Revelli et al., 2013).

Thus, this review will provide an insight into the different factors that affect ovarian functionality after transplantation and some relevant advance to date.

\section{Ovarian tissue transplantation}

The main goal of transplantation of ovarian tissue is the restoration of ovarian endocrine function and fertility especially in young and adult women undergoing cancer treatment (Donnez et al., 2013). The ovary is abundant in primordial follicles in the quiescence stage or at rest that constitute the ovarian reserve. Only a few of these will be activated and develop to an advanced follicular stage (Kim, 2012). Primordial follicles can be cryopreserved and stored at any stage of the female reproductive life, without the need for hormonal treatment.
The ovary is a well suited place for transplantation due to its naturally abundant angiogenic factors that favor the neovascularization process. According to the site of transplantation the procedure is classified as: orthotopic or heterotopic implantation. Orthotopic implantation is defined as tissue transplanted to its place of origin or into the pelvic cavity. In the case of heterotopic implantation, it is defined as tissue transplanted in a different site or in an extraovarian region (Sonmezer \& Oktay, 2010), such as the abdominal wall (Rodriguez-Wallberg \& Oktay, 2012), forearm (Oktay et al., 2001), kidney capsule (Youm et al., 2015) or breast (Kim et al., 2004) following the cryopreservation process.

According to the graft recipient, transplantation can be classified as xenotransplantation (performed in different species), allotransplantation (performed in the same species) or autotransplantation (performed in the same individual).

\section{Site of ovarian tissue implantation}

\section{Orthotopic site}

In this type of transplantation, the tissue is reimplanted in its original physiological surroundings and the development of transplanted tissue is very effective. The main advantage of orthotopic transplantation of ovarian tissue is that natural conception could occur without the intervention of assisted reproductive techniques. According to Donnez \& Dolmans (2015), the pelvic cavity (orthotopic site) would provide the optimal environment for follicular development compared with heterotopic sites, as temperature, pressure, paracrine factors and blood supply are similar to those observed in a physiological situation. Conversely, the disadvantage would be the limited number of fragments able to be transplanted due to ovary size. In addition, orthotopic transplantation is an invasive procedure that may cause severe pelvic adhesions (Demeestere et al., 2009).

In animal production, the first encouraging results were obtained by Gosden et al. (1994) in sheep. These authors reported the resumption of cyclic activity, pregnancy, and producing a live birth after orthotopic autotransplantation of samples of ovarian tissue cryopreserved by slow freezing. Subsequently, Salle et al. $(2002,2003)$ and Bordes et al. (2005) also reported live birth using orthotopic transplantation of a frozen-thawed and vitrified ovary in ewes. Imhof et al. (2006) also reported a live birth after orthotopic transplantation of frozen-thawed ovarian tissue in ovine. Moreover, Santos et al. (2009) demonstrated complete follicular development and the recovery of endocrine function after cryopreservation and orthotopic autotransplantation of small ovarian 
fragments in bilaterally ovariectomized goats without administration of hormones.

It should be emphasized that the first live birth in humans obtained using the combination of ovarian tissue cryopreservation and orthotopic transplantation was reported by Donnez et al. (2004), and was a landmark in human reproductive medicine. Since then, various authors have reported live birth after ovary transplantation (Andersen et al., 2008; Silber et al., 2008; Donnez et al., 2011, Silber, 2016).

Two techniques were successfully used to reimplant fresh or frozen-thawed ovarian tissue in an orthotopic site, within a specially created window on the peritoneum (Donnez et al., 2004) or on the remaining ovary (Donnez et al., 2006a). The large tissue strips (8$10 \times 5 \mathrm{~mm}$ ) of ovarian fragments could be sutured into the remaining ovary after the removal of the native cortex. However, the transplantation of small pieces $(2 \times 2 \mathrm{~mm})$, in the medulla space was difficult because it could not be sutured (Donnez et al., 2008). A normal reproductive lifespan was demonstrated after orthotopic grafting of vitrified ovary in the mouse (Liu et al., 2008). Furthermore, Silber et al. (2008) reported reinitiation of ovulatory menstrual cycles and normal serum FSH levels after 77-142 days after transplantation of fresh and cryopreserved ovarian tissue between a series of monozygotic (MZ) twin pairs. Moreover, two live births were reported following fresh ovary transplantation between two identical twin sisters and another one live birth after autotransplantation of cryopreserved ovarian tissue (Silber et al., 2008). Burmeister et al. (2013) also reported human pregnancy after ovarian tissue cryopreservation and subsequent orthotopic autotransplantation.

\section{Heterotopic site}

The potential advantages of heterotopic implantation include: avoidance of invasive procedures; easy accessibility of the graft; increased capacity for cortical slices; and feasibility for grafting even if severe pelvic adhesions preclude orthotopic transplantation (Kim, 2012). In addition, the use of general anaesthesia is not required and the removal of the transplanted fragments is not difficult (Filatov et al., 2016). However, unlike orthotopic transplantation, natural conception cannot be expected after transplantation of ovarian tissue to heterotopic sites and, therefore, in vitro fertilization (IVF) is required for conception.

As mentioned above, ovarian grafts can be transplanted in several different sites, including the bursa cavity, the kidney capsule, and subcutaneous sites. Transplantation in the kidney capsule has been often used due its excellent blood supply that would enhance graft survival (Youm et al., 2015). Graft recovery and oocyte yield are significantly higher from the bursal cavity and kidney capsule compared with subcutaneous site in murine species (Youm et al., 2015). Regardless of the site of transplantation, the ovarian graft will undergo ischemia and potential follicular atresia during the period after transplantation before tissue revascularization; this process remains a challenge to the success of this technique (Wang et al., 2012). However, by virtue of their low metabolic rate, primordial follicles are relatively resistant to the effects of oxygen deprivation (Schmidt et al., 2003).

Heterotopic ovarian transplantation experience in humans and non-human primates has been very limited (Amorim et al., 2013). Several heterotopic sites have been tested in humans, including the uterus broad ligament (Gosden et al., 2010), the rectus muscle (Kim et al., 2009), the forearm (Oktay et al., 2001), breast tissue (Kim et al., 2004), the subcutaneous tissue of the abdomen (Youm et al., 2015) and subperitoneal tissue (Stern et al., 2011). In studies with primates, other heterotopic sites (omentum, retroperitoneal iliac fossa, uterine serosa, mesosalpinx, and the pelvic wall) were also used (Suzuki et al., 2012). In addition to intraperitoneal (omentum) or subperitoneal sites, the subcutaneous tissue of the abdomen could also provide an adequate environment for follicle growth in both humans and primates (Kim, 2014). However, heterotopic sites may not provide an optimal environment for follicular development due to differences in temperature, paracrine factors and blood supply compared with the intraperitoneal environment (Donnez et al., 2010a). Primate models have been used to find suitable locations to overcome some of these challenges (Igarashi et al., 2010). High rates of follicular survival after heterotopic xenotransplantation of human cryopreserved prepubertal ovarian tissue in mice have been recently demonstrated with the retention of a large pool of dormant primordial follicles in the graft (Luyckx et al., 2013). Furthermore, Stern et al. (2013) reported the first clinical pregnancy following heterotopic grafting of cryopreserved ovarian tissue in a woman after a bilateral oophorectomy.

Therefore, the choice of the transplantation sites constitutes an essential factor involved in future graft viability and in the subsequent oocyte competence (Demeestere et al., 2009).

\section{Graft recipient of ovarian tissue implantation}

\section{Xenotransplantation}

Complex biological processes often require in vivo analysis, and several important research studies have been made using mice as a model for the study of various biological systems. Humanized mice, or mouse-human chimeras were developed to overcome these constraints and are now an important research tool for in vivo study of human cells and tissues 
(Shultz et al., 2007). Immunodeficient mice have been used to evaluate follicle development and survival after cryopreservation of ovarian tissue. Some studies (Table 1) have shown that xenografting of human ovarian tissue into mice has been an effective model to study ovarian function and follicle development in vivo (Van Eyck et al., 2009). Since 1960, athymic mice (nude) have been a standard for establishing in vivo models of human malignancies. Due to the lack of a thymus, nude mice cannot generate mature $\mathrm{T}$ lymphocytes and therefore are unable to mount most types of immune responses (Fransolet et al., 2015). This absence of functioning $\mathrm{T}$ cells prevents nude mice from rejecting not only allografts, but even xenografts (Fransolet et al., 2015). Another attractive model is the use of severe combined immunodeficient (SCID) mice (Fransolet et al., 2015). SCID mice were the first and are the most commonly used model for ovarian xenografts (Aubard, 2003) and were characterized by their scid mutation, which leads to a defect in the recombination of antigen receptor genes, impairing their capacity to generate functional $\mathrm{B}$ and $\mathrm{T}$ lymphocytes (Custer et al., 1985). Thus, SCID mice can maintain tissues from foreign species without demonstrating a graft-versushost response (Bosma et al., 1983) and, consequently, they can serve as a good model for transplantation studies. A few years after SCID mouse generation, the scid mutation was transferred onto a non-obese diabetic (NOD) background. This transfer leads to NOD-SCID mice, which have reduced natural killer cell (NK cell) activity in addition to the deficiency in functional B and T cells (Prochazka et al., 1992). Moreover, their ability to activate some components of the complement system is impaired, and these mice are markedly deficient in macrophages (Shultz et al., 2007).

In order to develop a novel protocol for the establishment of human ovarian stroma within a mouse model subcutaneously, normal human ovarian tissues were subcutaneously implanted into SCID mice and then the implants were identified by immunohistochemistry. The results demonstrated that human ovarian tissue successfully survives in a SCID mouse host and retains the properties of the original normal ovarian tissues (Fu et al., 2014). Previously, Luyckx et al. (2013) reported that frozenthawed preantral follicles from prepubertal patients can successfully survive and develop after long-term ovary xenografting. The study conducted by Henry et al. (2015) after xenotransplantation of sheep ovary to SCID and NOD-SCID showed that they were both suitable for studying graft recovery, however, based on histologic analysis, the overall tissue morphology was better preserved in SCID mice. A significant alteration of the gene responsible for ovarian metabolism and function was reported after xenotransplantation of rat ovary into the kidney capsule of immune-deficient mice (Agca et al., 2009). Ishijima et al. (2009) also showed high follicular loss after xenotransplantation of canine cryopreserved ovary in immune-deficient mice. Moreover, it was demonstrated that encapsulation of ovarian tissue with VEGF165 in a collagen matrix during xenografting in SCID mouse produces a more rapid onset of functional vessel formation and earlier revascularization of the transplant (Henry et al., 2015). Lotz et al. (2014) reported antral follicle formation after 122 days post xenotransplantation in a single human ovarian fragment of 6 years old without exogenous hormone stimulation. Moreover, it was shown that isolated human follicles were able to survive after encapsulation in fibrin clots and shortterm xenotransplantation (Paulini et al., 2016).

\section{Autotransplantation/allotransplantation}

As mentioned before, the main goal of ovarian tissue transplantation is the restoration of fertility and endocrine function of women who undergo cancer treatments (chemo-/radiotherapy). In this context, the efforts made so far by research teams from at least 10 countries have proved that transplantation of cryopreserved ovarian tissue is a promising option to preserve fertility in female patients with cancer. These procedures allow immediate initiation of cancer treatment, as it does not require prior ovarian stimulation nor sperm donation compared with other technologies such as embryo or oocyte cryopreservation.

It is very difficult to know the exact number of attempts made to transplant ovarian tissue (fresh and cryopreserved), especially when it is not directly involved with the clinic or even when the main focus of research is the biotechnology of animal production. In fact, according to Donnez \& Dolmans (2015), the number of reimplantations performed worldwide is not known. However, excellent results have been seen in the USA, Brussels, Paris, Spain, Denmark, and Israel. In addition, successes are reported by research teams in Japan, Italy, Germany, and Australia (Stoop et al., 2014). In addition to the excellent restoration rate of ovarian function $(95 \%)$ and a reasonable gestation rate $(23 \%)$ obtained when this strategy is applied, it has been observed that the duration of ovarian function has been maintained for a period from 4 to 5 years (Donnez \& Dolmans, 2013, 2014).

Autotransplantation of frozen and thawed ovarian tissue is only possible if absence of cancer cells in the graft is confirmed and there is a legitimate concern for the reseeding of malignant cells when carrying out ovarian transplantation (Rodriguez-Wallberg \& Oktay, 2012). Disadvantages of ovarian tissue cryopreservation and autotransplantation include the limited life span of the ovarian grafts due to the potential post-transplantation window of ischemia responsible 
Table 1 Summary of some relevant results obtained after xenotransplantation of ovarian tissue in different species

\begin{tabular}{|c|c|c|c|c|c|c|c|c|}
\hline $\begin{array}{l}\text { Species } \\
\text { involved }\end{array}$ & $\begin{array}{l}\text { Graft number } \\
\text { and size }\end{array}$ & Graft site & $\begin{array}{l}\text { Ovary } \\
\text { preparation }\end{array}$ & $\begin{array}{l}\text { Reproductive } \\
\text { stage of } \\
\text { ovary's donor }\end{array}$ & $\begin{array}{l}\text { Exogenous } \\
\text { substance }\end{array}$ & $\begin{array}{l}\text { Graft recovery } \\
\text { date }\end{array}$ & Outcome & References \\
\hline Rat to Mice & $1 \mathrm{~mm}^{3}$ & $\begin{array}{l}\text { Kidney } \\
\text { capsule }\end{array}$ & $\begin{array}{l}\text { Fresh and } \\
\text { frozen/thawed }\end{array}$ & $\begin{array}{l}\text { Adult } \\
\text { (3 weeks) }\end{array}$ & No & 10-12 weeks & $\begin{array}{l}\text { Alteration of genes responsible for } \\
\text { ovarian metabolism and function, } \\
\text { upregulated of genes responsible } \\
\text { for graft rejection }\end{array}$ & $\begin{array}{l}\text { Agca et al., } \\
2009\end{array}$ \\
\hline \multirow[t]{2}{*}{$\begin{array}{l}\text { Sheep to } \\
\text { Mice }\end{array}$} & $\begin{array}{l}1 \mathrm{pc}(2.5 \times 2.5 \times \\
1 \mathrm{~mm})\end{array}$ & Ovary & Frozen/thawed & Adult & VEGF 165 & $\begin{array}{l}3 \text { days or } \\
3 \text { weeks }\end{array}$ & $\begin{array}{l}\text { functional vessel formation and } \\
\text { earlier revascularization }\end{array}$ & $\begin{array}{l}\text { Henry et al., } \\
2015\end{array}$ \\
\hline & $\begin{array}{l}1 \mathrm{pc}(2.5 \times 2.5 \times \\
1 \mathrm{~mm})\end{array}$ & Ovary & Frozen/thawed & Adult & VEGF 111 & $\begin{array}{l}3 \text { days or } \\
3 \text { weeks }\end{array}$ & $\begin{array}{l}\text { SCID mice is best murine model for } \\
\text { studying ovarian tissue } \\
\text { xenografts }\end{array}$ & $\begin{array}{l}\text { Fransolet } \\
\text { et al., } 2015\end{array}$ \\
\hline $\begin{array}{l}\text { Bovine to } \\
\text { Mice }\end{array}$ & $\begin{array}{l}1 \text { pc }(1-2 \text { or } \\
0.5-0.9 \mathrm{~mm})\end{array}$ & Subcutaneous & Frozen/thawed & Adult & No & 7 days & $\begin{array}{l}\text { Follicle activation and 'burn out' } \\
\text { induce follicles loss after } \\
\text { transplantation }\end{array}$ & $\begin{array}{l}\text { Gavish } \\
\quad \text { et al., } 2014\end{array}$ \\
\hline \multirow[t]{5}{*}{$\begin{array}{l}\text { Human to } \\
\text { Mice }\end{array}$} & 1 pc $(1 \times 2 \times 1 \mathrm{~mm})$ & Intramuscular & Frozen/thawed & $\begin{array}{l}\text { Children } \\
\text { (6 year) }\end{array}$ & No & 122 days & Antral follicle formation & $\begin{array}{l}\text { Lotz et al., } \\
2014\end{array}$ \\
\hline & $\begin{array}{l}2 \mathrm{pc}(5 \times 1.5 \times \\
1 \mathrm{~mm})\end{array}$ & Intraperitoneal & $\begin{array}{l}\text { Fresh and } \\
\text { frozen/thawed }\end{array}$ & $\begin{array}{l}\text { Adult }(20- \\
30 \text { years })\end{array}$ & FSH and hCG & 28 weeks & $\begin{array}{l}\text { Antral follicles obtained after } \\
\text { grafting of frozen-thawed human } \\
\text { ovarian tissue showed a thinner } \\
\text { theca cell layer compared with } \\
\text { those from fresh grafts }\end{array}$ & $\begin{array}{l}\text { Amorim } \\
\text { et al., } 2011\end{array}$ \\
\hline & $\begin{array}{l}1-2 \text { pc }(1 \times 3 \text { or } \\
8-10 \mathrm{~mm})\end{array}$ & Intraperitoneal & Frozen/thawed & $\begin{array}{l}\text { Children }(7.2- \\
12.2 \text { years })\end{array}$ & FSH & 21 weeks & Antral follicles formation & $\begin{array}{l}\text { Luyckx } \\
\text { et al., } 2013\end{array}$ \\
\hline & $2 \mathrm{pc}(2 \times 4 \mathrm{~mm})$ & Intraperitoneal & Frozen/thawed & $22-38$ years & No & 2 and 7 days & $\begin{array}{l}\text { Alteration of gene expression after } \\
\text { human ovarian tissue } \\
\text { xenografting }\end{array}$ & $\begin{array}{l}\text { Van } \\
\text { Langen- } \\
\text { donckt } \\
\text { et al., } 2014\end{array}$ \\
\hline & 6 pc $(1 \times 1 \times 1 \mathrm{~mm})$ & Intramuscular & $\begin{array}{l}\text { Fresh and } \\
\text { vitrified }\end{array}$ & $\begin{array}{l}\text { Adult }(21- \\
35 \text { years })\end{array}$ & No & 30 days & $\begin{array}{l}\text { Evidence on the significant effect of } \\
\text { vitrification on follicular } \\
\text { apoptosis of grafted human } \\
\text { ovarian tissue at mRNA level }\end{array}$ & $\begin{array}{l}\text { Jafarabadi } \\
\text { et al., } 2015\end{array}$ \\
\hline $\begin{array}{l}\text { Human to } \\
\text { Rabbit }\end{array}$ & $2 \mathrm{pc}$ & Back muscle & Fresh & $\begin{array}{l}\text { Adult }(30- \\
35 \text { years })\end{array}$ & $\begin{array}{l}\text { VEGF, bEGF } \\
\text { and } \mathrm{hMG}\end{array}$ & 6 weeks & $\begin{array}{l}\text { VEGF and bFGF, especially the } \\
\text { combination of them, triggered } \\
\text { angiogenesis, reduced apoptosis } \\
\text { and fibrosis, increased survival in } \\
\text { transplanted human ovarian } \\
\text { tissue }\end{array}$ & $\begin{array}{l}\text { Wang et al., } \\
2013\end{array}$ \\
\hline
\end{tabular}

Pc: piece. 
for follicular atresia. In addition, for patients with autoimmune or genetic disorders, gonadal autotransplantation is ineffective in preserving fertility. In such cases, allotransplantation might be the solution (Yi-Hsin et al., 2011). Silber and colleagues reported a series of monozygotic twins (Table 2) who underwent ovarian isotransplantation to rescue the sterile sister (Silber et al., 2005, 2008). Furthermore, orthotopic ovarian allotransplantation has been performed in patients diagnosed with Turner's syndrome. This technique was able to restore regular menstruation and ovulation, it raised hormonal concentrations and led to the development of secondary sexual characters (Mhatre \& Mhatre, 2006). However, Scott et al. (1987) have shown that immunosuppressive therapy, such as cyclosporine A plus steroid, is needed for ovarian allografts to survive.

\section{Factors affecting graft function}

Follicle loss is one of the major limitations after ovary transplantation. This phenomenon occurs in several steps of the procedure as cited below.

\section{Ovarian tissue size}

The thickness of ovarian cortical strips prior to freezing is critical to enable the perfusion of cryoprotectants and the ensuring of the graft survival. The surfaceto-volume ratio of the graft has to be high in order to ensure good penetration and removal of cryoprotectants agents. It reduces the probability of damage caused by ice crystals during freezing and thawing, and by the ischemia and hypoxia that occurs during the initial steps of graft acceptance (Gavish et al., 2008). Currently, ovarian cortical tissue is cryopreserved in strips of 1-2 mm thickness either by slow freezing or vitrification protocols (Kagawa et al., 2009). It has been suggested (Gavish et al., 2008; Revel et al., 2011) that reducing graft dimensions might enhance diffusion of oxygen, growth factors and nutrients into the ischemic graft and improve follicle's survival. However, a study conducted by Gavish et al. (2014) showed an extensive neovascularization 1-week post xenotransplantation of bovine ovarian tissue in mice. No beneficial effect was found when reducing the graft thickness beyond $1 \mathrm{~mm}$, including extensive primordial follicle loss and increased follicle 'burn out' without improving neovascularization. Moreover, the transplanted fragments of ovarian cortex contain only a fraction of an individual's ovarian reserve and as such can only provide the recipient with a relatively brief fertile window before the supply of oocytes contained within their graft is depleted (Andersen et al., 2008; Ernst et al., 2010; Silber, 2012; Donnez et al.,
2013). This limitation means that cryopreservation and autografting of pieces of cortex appear to be less effective as a means to restore the fertility of older patients in whom follicle density is already low at the time of tissue preservation and in which it is associated with endocrine disturbance (Campbell et al., 2004). In this context, cryopreservation of the whole ovary (complete with vascular pedicle) for later autotransplantation provides an attractive alternative strategy for fertility preservation as it involves restoration of all of the primordial follicles within the ovary. Furthermore, as transplantation requires vascular anastomosis rather than cortical revascularization, this intervention should result in no marked reduction of ovarian reserve due to ischemia, preventing endocrine imbalance and reducing the age constraint which limit the efficacy of this fertility preservation technology (Campbell et al., 2014). However, autotransplantation of frozenthawed whole ovary has also some disadvantages including:

(1) It has a higher risk of cryoinjury during freezing due to inadequate diffusion of cryoprotectants throughout the entire ovary and non-homogenous cooling rate between the core and the periphery of the ovary as well.

(2) Cryoinjury of ovarian vasculature

(3) Surgical difficulty of vascular anastomosis due to the small size of ovarian artery $(\sim 0.5 \mathrm{~mm}$ in diameter), short ovarian vascular pedicle $(\sim 5 \mathrm{~cm}$ in length), discrepancy between the diameters of graft and recipient vessels, and possible failure of microvascular anastomosis.

(4) Higher risk of post-operative vascular complications including anastomotic bleeding, pseudoaneurysm, stenosis, or microvascular thrombosis.

(5) Its vascular complications can severely affect the survival of the entire ovary leaving no other attempt for transplantation (Bedaiwy \& Falcone 2010; Kim, 2010; Zhang et al., 2011).

\section{Ischemia}

Ischemia is defined as the insufficient perfusion and reduction of the arterial or venous blood flow, depletion of cellular energy storages, and the accumulation of toxic metabolites which can lead to cell death (Ingec et al., 2011). Ischemic times that extend for several days most likely induce profound and irreversible ischemia-reperfusion injuries. They are responsible for follicle loss, as the graft needs 45 days to be reoxygenated (Van Eyck et al., 2009). A study with sheep ovarian tissue reported that $65 \%$ of the follicles are lost after grafting of fresh tissue while subjecting the tissue to cryopreservation and thawing 
Table 2 Summary of some relevant results obtained after auto/allotransplantion of ovarian tissue in different species

\begin{tabular}{|c|c|c|c|c|c|c|c|c|}
\hline Speciea & $\begin{array}{l}\text { Transplantation } \\
\text { type }\end{array}$ & $\begin{array}{l}\text { Graft number } \\
\text { and size }\end{array}$ & Graft site & $\begin{array}{l}\text { Reproductive } \\
\text { stage of } \\
\text { ovary's donor }\end{array}$ & $\begin{array}{l}\text { Ovary } \\
\text { preparation }\end{array}$ & $\begin{array}{l}\text { Exogenous } \\
\text { substance } \\
\text { injected }\end{array}$ & Outcome & References \\
\hline \multirow[t]{2}{*}{ Mice } & Allotransplanted & $\begin{array}{l}\text { Whole ovary } \\
\qquad\left(2 \mathrm{~mm}^{3}\right)\end{array}$ & Ovarian bursa & Immature (10 days) & $\begin{array}{l}\text { Fresh and frozen/ } \\
\text { thawed }\end{array}$ & No & 15 Live birth & $\begin{array}{l}\text { Candy et al., } \\
2000\end{array}$ \\
\hline & Allotransplanted & $\begin{array}{l}\text { 1, } 2 \text { or } 4 \mathrm{pc} \\
\text { Hemi-ovary }\end{array}$ & $\begin{array}{l}\text { Kidney capsule, } \\
\text { subcutaneous, bursa }\end{array}$ & Adult (3 weeks) & Fresh & PMSG & 19 live birth & $\begin{array}{l}\text { Yang et al., } \\
2006\end{array}$ \\
\hline Goat & Autotransplanted & 15 slides $\left(1 \mathrm{~mm}^{3}\right)$ & Uterus & Adult & Frozen-thawed & No & $\begin{array}{l}\text { Restoration of } \\
\text { ovarian } \\
\text { function }\end{array}$ & $\begin{array}{l}\text { Santos et al., } \\
2009\end{array}$ \\
\hline \multirow[t]{4}{*}{ Sheep } & Autotransplanted & Hemi-ovary & Hilus & $\begin{array}{l}\text { Immature } \\
\text { (6 months to } 1 \text { year })\end{array}$ & Frozen/thawed & No & 6 live birth & $\begin{array}{l}\text { Salle et al., } \\
\quad 2003\end{array}$ \\
\hline & Autotransplanted & Whole ovary & Uterus & $\begin{array}{l}\text { Immature } \\
\text { (6 months) }\end{array}$ & Frozen/thawed & No & 1 live birth & $\begin{array}{l}\text { Imhof et al., } \\
\quad 2006\end{array}$ \\
\hline & Autotransplanted & Whole ovary & Rectus muscle & Adult ( $2-3$ years) & Frozen/thawed & Chronogest sponge & $\begin{array}{l}\text { Restoration of } \\
\text { ovarian } \\
\text { function }\end{array}$ & $\begin{array}{l}\text { Grazul- } \\
\text { Bilska } \\
\text { et al., } 2008\end{array}$ \\
\hline & Autotransplanted & Whole ovary & Uterine horn & Adult (3-6 years) & Frozen/thawed & Aspirin, S1P, Vit E & 7 live birth & $\begin{array}{l}\text { Campbell } \\
\text { et al., } 2014\end{array}$ \\
\hline \multirow[t]{10}{*}{$\begin{array}{l}\text { Non-human } \\
\text { Primates }\end{array}$} & Autotransplanted & $1 \mathrm{~mm}$ & Subcutaneous & Adult (4-6 years) & $\begin{array}{l}\text { Fresh and frozen/ } \\
\text { thawed }\end{array}$ & VEGF & $\begin{array}{l}\text { Restoration of } \\
\text { ovarian } \\
\text { function }\end{array}$ & $\begin{array}{l}\text { Schnorr et al., } \\
2002\end{array}$ \\
\hline & Autotransplanted & $8 \times 3 \times 1 \mathrm{~mm}$ & Decorticate ovary & Adult & Vitrified/warmed & No & $\begin{array}{l}\text { successful } \\
\text { ovulation }\end{array}$ & $\begin{array}{l}\text { Amorim } \\
\text { et al., } 2013\end{array}$ \\
\hline & Allotransplanted & $1-2 \mathrm{~mm}$ & Ovary medulla & Adult (24 years) & Fresh & No & 1 live birth & $\begin{array}{l}\text { Silber et al., } \\
\quad 2005\end{array}$ \\
\hline & Autotransplanted & $5 \times 5 \times(1-2 \mathrm{~mm})$ & Subperitoneal wall & Adult (26-35 years) & Frozen/thawed & No & 2 live birth & $\begin{array}{l}\text { Andersen } \\
\text { et al., } 2008\end{array}$ \\
\hline & Allotransplanted & $1 \mathrm{~mm}$, whole ovary & $\begin{array}{l}\text { Ovary medulla, uterine } \\
\text { horn }\end{array}$ & Adult (24-40 years) & $\begin{array}{l}\text { Fresh and frozen/ } \\
\text { thawed }\end{array}$ & No & $\begin{array}{r}3 \text { live birth, } 3 \\
\text { pregnancy }\end{array}$ & $\begin{array}{l}\text { Silber et al., } \\
2008\end{array}$ \\
\hline & Allotransplanted & $\begin{array}{l}10 \times 6 \mathrm{~mm} \text { and } \\
2 \times 1 \mathrm{~cm}\end{array}$ & Ovary medulla & Adult (32 an 35 years) & Fresh & No & $\begin{array}{l}\text { Restoration of } \\
\text { ovarian } \\
\text { function }\end{array}$ & $\begin{array}{l}\text { Donnez et al. } \\
\text { 2010b }\end{array}$ \\
\hline & Allotransplanted & $2 \times 1 \mathrm{~cm}$ & Ovary medulla & Adult (36 years) & Fresh & rec-hFSH, GNRH & 1 live birth & $\begin{array}{l}\text { Donnez et al., } \\
2011\end{array}$ \\
\hline & Autotransplanted & $10 \mathrm{pc}\left(5 \times 5 \mathrm{~mm}^{2}\right)$ & Subcapsular & Adult (37 years) & Frozen/thawed & Choriogonadotr-opin & 1 live birth & $\begin{array}{l}\text { Burmeister } \\
\text { et al., } 2013\end{array}$ \\
\hline & Autotransplanted & $30 \mathrm{pc}(1 \times 2 \times 4 \mathrm{~mm})$ & Intraperitoneal & Adult (21 years) & Frozen/thawed & FSH, LH, GnRH & pregnancy & $\begin{array}{l}\text { Stern et al., } \\
2013\end{array}$ \\
\hline & Autotransplanted & $10-12 \mathrm{pc} 1 \times 3 \times 5 \mathrm{~mm}$ & $\begin{array}{l}\text { Peritoneal and } \\
\text { subperitoneal } \\
\text { pockect, abdominal } \\
\text { wall }\end{array}$ & Adult (23 years) & Frozen/thawed & Gonadotropin & 1 live birth & $\begin{array}{l}\text { Rodriguez- } \\
\text { Wallberg } \\
\text { et al., } 2015\end{array}$ \\
\hline
\end{tabular}


would add another $7 \%$ of follicle loss (Baird et al., 1999). Moreover, fresh or frozen human ovarian grafts transplanted into nude mice showed similar reduction in follicular density, demonstrating that ischemia is the main factor behind follicular depletion (Demeestere et al., 2009). Thus, duration of warm ischemia before neovascularization is crucial for follicular survival and may be responsible for the major loss of follicles after grafting rather, than after freezing.

The mechanisms behind ischemic injury involves energy depletion and reperfusion oxidative stress (Demeestere et al., 2009), which can cause damage to lipids, DNA, enzymes and structural proteins, therefore leading to cell death (Kim et al., 2003). Gene expression of several inflammatory factors is initiated by hypoxia-sensitive response elements and nuclear factor-kappa beta (NF-кB), resulting in transmigration of neutrophils and macrophages into the tissue (Vollmar et al., 1995) that causes tissue destruction and fibrosis. However, primordial follicles still survive for relatively long periods of ischemia after avascular transplantation due to their very low metabolic demands. Moreover, they are distributed just under the ovarian surface and they may be the first to benefit from the ingrowth of new vessels. In a study with cryopreserved bovine ovarian cortex it was demonstrated that stromal cells are more vulnerable to ischemia compared with primordial follicles (Kim et al., 2004). Due to the negative effects of ischemic time in the follicular pool, angiogenesis is the key mechanism for follicle survival.

\section{Addition of exogenous substances to improve angiogenesis and ovarian graft}

Many animal experiments have focused on improving ovarian tissue survival. Transplantation of frozenthawed ovarian tissue in animal models led to antral follicle development and live birth (Schubert et al., 2008). However, despite the successful results obtained with cryopreservation and autotransplantation of ovarian tissue, it is important to highlight the large follicle loss resulting from the latter procedure (Gavish et al., 2014). In this context, many studies have been conducted with different substances such as antioxidants agents or angiogenic factors. Local antioxidant injection of vitamin E before grafting could improve follicular survival rate (Martinez-Madrid et al., 2009). Ischemia and oxidative stress could be reduced by using drugs to stimulate revascularization of the graft, such as vascular endothelial growth factor or sphingosine-1-phosphate (S1P), as described by Donnez \& Dolmans, (2013). A study carried out by Zelinski et al. (2011) showed that S1P and its analogues protected the primate ovary against radiation-induced damage. In addition, Scalercio et al. (2015) showed that trolox, an analogue of vitamin E improved follicular quality and avoided apoptosis in stromal cells when ovarian tissue is pre-treated with this substance. Moreover, a study showed that autografted mice ovary followed by daily administration of L-carnitine until day 7 inhibited follicle apoptosis, relieved oxidative damage, and increased follicular survival and function in ovarian graft (Zhang et al., 2015).

To reduce the hypoxic period after tissue transplantation and improve follicular preservation, angiogenesis can be stimulated by vascular endothelia growth factor (VEGF), which is the main signaling protein that regulates new vessel formation from pre-existing vessels (Henry et al., 2015).

Ovarian cryopreservation and transplantation procedures have so far been almost exclusively limited to avascular cortical fragments. The small cortical pieces grafted without vascular anastomosis are completely dependent on the establishment of neovascularization after grafting. Consequently, the cells in the graft undergo significant ischemic and reperfusion damage, which can induce a high rate of follicular loss (Zhang et al., 2016). Therefore, these cells remain quiescent until there is an angiogenic stimulus such as hypoxia or wounding, which then up-regulates proangiogenic factors, such as VEGF (Gerhardt \& Betsholtz, 2003). Angiogenesis is regulated in the reproductive tract and elsewhere by at least 20 angiogenic growth factors and inhibitors identified to date. A key player is VEGF also known as vascular permeability factor (Ferrara and Davis-Smyth, 1997). It has been shown that VEGF acts via two tyrosine kinase family receptors, namely flt-1 (VEGF receptor; VEGFR-1) and flk1/KDR (Ferrara and Davis-Smyth, 1997), which are expressed in granulosa cells (Greenaway et al., 2004). The effects of two VEGF-A isoforms, VEGF111 and VEGF165, have been tested in a xenograft model using SCID mice (Commin et al., 2012). VEGF111 is soluble and resistant to proteolysis, whereas VEGF165 is additionally anchored to the extracellular matrix. Both VEGF isoforms increase blood vessel recruitment and functional angiogenesis. The use of this isoform in a collagen matrix, which encapsulates the ovarian cortex at the time of transplantation was found to improve angiogenesis and decrease hypoxia, thereby enhancing the preservation of primary follicles (Labied et al., 2013). Moreover, it was demonstrated (Henry et al., 2015) that encapsulation of ovarian tissue with VEGF165 in a collagen matrix during xenografting in mice produces a more rapid onset of functional vessel formation and earlier revascularization of the transplant. In addition, Campbell et al. (2014) used a post-operative regime of anti-thrombotic (aspirin) agents to reduce post-transplant ischemia. 
This substance prevents clot formation in the ovarian vasculature induced by cryo- and cyto-toxic damage to the arterial endothelial cells.

\section{Final considerations}

This review reinforces the fact that cryopreservation of ovarian tissue for further transplantation is helpful for prepubertal and women of reproductive age or patients for whom cancer treatment cannot be delayed to perform another assisted reproductive technique such as oocyte or embryo cryopreservation. Because preparation and stimulation for oocyte retrieval usually requires 2 to 3 weeks or longer, it is generally not feasible to freeze embryos from an adult female cancer patient for potential future use. Additionally, not all patients have partners with whom they can produce embryos to cryopreserve. Moreover, in contrast with oocytes and embryos, cryopreservation of ovarian tissue does not depend on the age and phase of the patient's estrous cycle, it also involves fewer ethical and social issues especially when this process is performed in humans.

Most of the experimental studies conducted with the transplant of cryopreserved ovarian tissue have the aim to re-establish fertility. However, in special situations, when it is necessary to remove the normal ovaries due to cancer or infectious processes of the pelvic organs, the absence of ovarian hormones may lead to several endocrine and functional disorders such as osteoporosis, reduction of libido, sexual dysfunction, and enhancement of lipoprotein levels. In such conditions, transplantation of cryopreserved ovarian tissue is the main solution to overcome this problem. However, despite the good results obtained by ovary cryopreservation following transplantation, it appears that the main obstacle to successfully restore fertility from frozen-thawed ovarian cortex are adhesions and the massive ischemic damage to follicles until neovascularization develops. Most follicles surviving cryopreservation will undergo ischemic loss during the time required for neovascularization.

Therefore, the optimization of ovary transplantation may require preparing the right thickness of tissue and finding the best site of transplantation. This could avoid ischemia and promote rapid revascularization. Angiogenesis is a key factor for graft survival because right after transplantation the lack of connective tissue between the graft and surrounded tissue is leading to hypoxia resulting in cell death. In this context reducing the ischemia period could enhance the success of transplantation. In this case, further animal model studies are required to develop optimized cryopreservation/transplant protocols for women.

\section{Acknowledgements}

Nathalie Jiatsa Donfack is a recipient of a grant from Coordenação de Aperfeiçoamento de Pessoal de Nível Superior (Brazil). Ana Paula Ribeiro Rodrigues is recipient of a grant from CNPq Brazil (473968/2013-4). Johan Smitz is Special Visitor Researcher from CAPES. None of the authors has any conflict of interest to declare.

\section{References}

Agca, C., Lucy, M.C. \& Agca, Y. (2009). Gene expression profile of rat ovarian tissue following xenotransplantation into immune-deficient mice. Reproduction 137, 957-67.

Amorim, C.A., David, A., Dolmans, M.M., Camboni, A., Donnez, J. \& Langendonckt, A.V. (2011). Impact of freezing and thawing of human ovarian tissue on follicular growth after long-term xenotransplantation. J. Assist. Reprod. Genet. 28, 1157-65.

Amorim, C.A., Jacobs, S., Devireddy, R.V., Langendonckt, A.V., Vanacker, J., Jaeger, J., Luyckx, V., Donnez, J. \& Dolmans, M.M. (2013). Successful vitrification and autografting of baboon (Papio anubis) ovarian tissue. Hum. Reprod. 28, 2146-56.

Anderson, R.A. \& Wallace, W.H.B. (2013). Antimullerian hormone, the assessment of the ovarian reserve and the reproductive outcome of the young patient with cancer. Fertil. Steril. 99, 14 69-75.

Andersen, C.Y., Rosendahl, M., Byskov, A.G., Loft, A., Ottosen, C., Dueholm, M., Kirsten, L.T. Schmidt KL.T., Andersen, A.N. \& Ernst, E. (2008). Two successful pregnancies following autotransplantation of frozen/thawed ovarian tissue. Hum. Reprod. 23, 2266-72.

Aubard, Y. (2003). Ovarian tissue xenografting. Eur. J. Obstet. Gynecol. Reprod. Biol. 108, 14-8.

Baird, D.T., Webb, R., Campbell, B.K., Harkness, L.M. \& Gosden, R.G. (1999). Long-term ovarian function in sheep after ovariectomy and transplantation of autografts stored at $-196^{\circ} \mathrm{C}$. Endocrinology 140, 462-71.

Bedaiwy, M.A. \& Falcone, T. (2010). Whole ovary transplantation. Clin. Obstet. Gynecol. 53, 797-803.

Bordes, A., Lornage, J., Demirci, B., Franck, M., Courbiere, B., Guerin, J.F. \& Salle, B. (2005). Normal gestations and live births after orthotopic autograft of vitrified-warmed hemi-ovaries into ewes. Hum. Reprod. 20, 2745-8.

Bosma, G.C., Custer, R.P. \& Bosma, M.J. (1983). A severe combined immunodeficiency mutation in the mouse. Nature 301, 527-30.

Burmeister, L., Kovacs, G.T. \& Osianlis, T. (2013). First Australian pregnancy after ovarian tissue cryopreservation and subsequent autotransplantation. Med. J. Aust. 198, 158-9.

Campbell, B.K., Telfer, E.E., Webb, R. \& Baird, D.T. (2004). Evidence of a role for follicle-stimulating hormone in controlling the rate of preantral follicle development in sheep. Endocrinology 145, 1870-9.

Campbell, B.K., Hernandez-Medrano, J., Onions, V., PincottAllen, C., Aljaser, F., Fisher, J., McNeilly, A.S., Webb, R. \& 
Picton, H.M. (2014). Restoration of ovarian function and natural fertility following the cryopreservation and autotransplantation of whole adult sheep ovaries. Hum. Reprod. 29, 1749-63.

Candy, C.J., Wood, M.J. \& Whittingham, D.G. (2000). Restoration of a normal reproductive lifespan after grafting of cryopreserved mouse ovaries. Hum. Reprod. 15, 1300-4.

César, J.M., Petroianu, A., Vasconcelos, L. de, S., Cardoso, V.N., Mota, L.D., Barbosa, A.J., Soares, C.D. \& De Oliveir, A.L. (2015). Preliminary study of coconut water for graft tissues preservation in transplantation. Rev. Col. Bras. Cir. $42,43-8$.

Commin, L., Buff, S., Rosset, E., Galet, C., Allard, A., Bruyere, P., Joly, T., Guerin, P. \& Neto, V. (2012). Follicle development in cryopreserved bitch ovarian tissue grafted to immunodeficient mouse. Reprod. Fertil. Dev. 24, 46.

Custer, R.P., Bosma, G.C. \& Bosma, M.J. (1985). Severe combined immunodeficiency (SCID) in the mouse. Pathology, reconstitution, neoplasms. Am. J. Pathol. 120, 464-77.

Demeestere, I., Simon, P., Emiliani, S., Delbaere, A. \& Englert, Y. (2009). orthotopic and heterotopic ovarian tissue transplantation. Hum. Reprod. Update 15, 649-65.

Demeestere, I., Simon, P., Moffa, F., Delbaere, A. \& Englert, Y. (2010). Birth of a second healthy girl more than 3 years after cryopreserved ovarian graft. Hum. Reprod. 25, 1590-1.

Donnez, J. \& Dolmans, M.M. (2013). Fertility preservation in women. Nat. Rev. Endocrinol. 9, 735-49.

Donnez, J. \& Dolmans, M.M. (2014). Transplantation of ovarian tissue. Best Pract. Res. Clin. Obstet. Gynaecol. 28, 1188-97.

Donnez, J. \& Dolmans, M.M. (2015). Ovarian cortex transplantation: 60 reported live births brings the success and worldwide expansion of the technique towards routine clinical practice. J. Assist. Reprod. Genet. 32, 116770.

Donnez, J., Dolmans, M.M., Demylle, D., Jadoul, P., Pirard, C., Squifflet, J., Martinez-Madrid, B. \& Van Langendonckt, A. (2004). Live birth after orthotopic transplantation of cryopreserved ovarian tissue. Lancet 364, 1405-10.

Donnez, J., Dolmans, M.M., Demylle, D., Jadoul, P., Pirard, C., Squifflet, J., Martinez-Madrid, B. \& Van Langendonckt, A. (2006a). Restoration of ovarian function after orthotopic (intraovarian and periovarian) transplantation of cryopreserved ovarian tissue in a woman treated by bone marrow transplantation for sickle cell anaemia: case report. Hum. Reprod. 21, 183-8.

Donnez, J., Martinez-Madrid, B., Jadoul, P., Van Langendonckt, A., Demylle, D. \& Dolmans, M.M. (2006b). Ovarian tissue cryopreservation and transplantation: a review. Hum. Reprod. Update 12, 519-35.

Donnez, J., Squifflet, J., Van Eyck, A.S., Demylle, D., Van Langendonckt, A. \& Dolmans, M.M. (2008). Restoration of ovarian function in orthotopically transplanted cryopreserved ovarian tissue: a pilot experience. Reprod. Biomed. Online 16, 694-704.

Donnez, J., Jadoul, P., Squifflet, J., Van Langendonckt, A., Donnez, O., Van Eyck, A.S., Marinescu, C. \& Dolmans, M.M. (2010a). Ovarian tissue cryopreservation and transplantation in cancer patients. Best Pract. Res. Clin. Obstet. Gynecol. 24, 87-100.

Donnez, J., Squifflet, J., Pirard, C., Jadoul, P. \& Dolmans, M.M. (2010b). Restoration of ovarian function after allografting of ovarian cortex between genetically nonidentical sisters. Hum. Reprod. 25, 2489-95.

Donnez, J., Squifflet, J., Pirard, C., Demylle, D., Delbaere, A., Armenio, L., Englert, Y., Cheron, A.C., Jadoul, P. \& Dolmans, M.M. (2011). Live birth after allografting of ovarian cortex between genetically non-identical sisters. Hum. Reprod. 26, 1384-8.

Donnez, J., Dolmans, M.M., Pellicer, A., Diaz-garcia, C., Serrano, M.S., Schmidt, K.T., Ernst, E., Luyckx, V. \& Andersen, C.Y. (2013). Restoration of ovarian activity and pregnancy after transplantation of cryopreserved ovarian tissue: a review of 60 cases of reimplantation. Fertil. Steril. 99, 1503-13.

Ernst, E., Bergholdt, S., Jorgensen, J.S. \& Andersen, C.Y. (2010). The first woman to give birth to two children following transplantation of frozen/thawed ovarian tissue. Hum. Reprod. 25, 1280-1.

Fassbender, M., Hildebrandt, T.B., Paris, MC.J., Colenbrander, B. \& Jewgenow, K. (2007). High-resolution ultrasonography of xenografted domestic cat ovarian cortex. J. Reprod. Dev. 53, 1023-34.

Ferrara, N. \& Davis-Smyth, T. (1997). The biology of vascular endothelial growth factor. Endocrine Ver. 18, 4-25.

Filatov, M.A., Khramova, Y.V., Kiseleva, M.V., Malinova, I.V., Komarova, E.V. \& Semenova, M.L. (2016). Female fertility preservation strategies: cryopreservation and ovarian tissue in vitro culture, current state of the art and future perspectives. Zygote 24, 635-53.

Fransolet, M., Henry, L., Labied, S., Masereel, M.C., Blacher, S., Noël, A., Foidart, J.M., Nisolle, M. \& Munaut, C. (2015). Influence of mouse strain on ovarian tissue recovery after engraftment with angiogenic factor. J. Ova. Res. 15, 142-6.

Fu, S., Wang, J., Sun, W., Xu, Y., Zhou, X. \& Cheng, W. (2014). Preclinical humanized mouse model with ectopic ovarian tissues. Exp. Therapeut. Med. 8, 742-6.

Gavish, Z., Ben-Haim, M. \& Arav, A. (2008). Cryopreservation of whole murine and porcine livers. Rejuvenation Res. 11, 765-72.

Gavish, Z., Peer, G., Hadassa, R., Yoram, C. \& Meirow, D. (2014). Follicles activation and burn-out contribute to posttransplantation follicles loss in ovarian tissue grafts: the effect of graft thickness. Hum. Reprod. 29, 989-96.

Gerhardt, H. \& Betsholtz, C. (2003). Endothelial-pericyte interactions in angiogenesis. Cell Tissue Res. 314, 15-23.

Gosden, R.G., Baird, D.T., Wade, J.C. \& Webb, R. (1994). Restoration of fertility to oophorectomized sheep by ovarian autografts stored at $-196^{\circ} \mathrm{C}$. Hum. Reprod. 9, 597603.

Gosden, R.G., Robert, T. \& Morris, M.D. (2010). Appreciation of an enlightened surgeon and pioneer of ovarian transplantation. Fertil. Steril. 94, 1960-3.

Grazul-Bilska, A.T., Banerjee, J., Yazici, I., Borowczyk, E., Bilski, J.J., Sharma, R.K., Siemionov, M. \& Falcone, T. (2008). Morphology and function of cryopreserved whole ovine ovaries after heterotopic autotransplantation. Reprod. Biol. Endocrinol. 6, 1-15. 
Greenaway, J., Connor, K., Hanne, G., Pedersen, Brenda, L., Coomber, Lamarre, J. \& Petrik, J. (2004). Vascular endothelial growth factor and its receptor, Flk-1/KDR, are cytoprotective in the extravascular compartment of the ovarian follicle. Endocrinology 145, 2896-905.

Henry, L., Labied, S., Fransolet, M., Kirschvink, N., Blacher1, S., Noël, A., Foidart, J.M., Nisolle, M. \& Munaut, C. (2015). Isoform 165 of vascular endothelial growth factor in collagen matrix improves ovine cryopreserved ovarian tissue revascularisation after xenotransplantation in mice. Reprod. Biol. Endocrinol. 13, 12.

Igarashi, S., Suzuki, N., Hashimoto, S., Takae, S., Takenoshita, M., Hosoi, Y., Morimoto, Y. \& Ishizuka, B. (2010). Heterotopic autotransplantation of ovarian cortex in cynomolgus monkeys. Hum. Cell 23, 26-34.

Imhof, M., Bergmeister, H., Lipovac, M., Rudas, M., Hofstetter, G. \& Huber, J. (2006). Orthotopic microvascular reanastomosis of whole cryopreserved ovine ovaries resulting in pregnancy and live birth. Fertil. Steril. 85, 1208-15.

Ingec, M., Isaoglu, U., Yilmaz, M., Calik, M., Polat, B., Alp, H.H., Kurt, A., Gundogdu, C. \& Suleyman, H. (2011). Prevention of ischemia-reperfusion injury in rat ovarian tissue with the on-off method. J. Physiol. Pharmacol. 62, 575-82.

Ishijima, T., Abe, Y. \& Suzuki, H. (2009). Loss of the cryopreserved canine ovary after xenotransplantation. J. Mamm. 26, 61-5.

Jafarabadi, M., Abdollahi, M. \& Salehnia, M. (2015). Assessment of vitrification outcome by xenotransplantation of ovarian cortex pieces in $\gamma$-irradiated mice: morphological and molecular analyses of apoptosis. J. Assist. Reprod. Genet. 32, 195-205.

Jemal, A., Siegel, R., Xu, J. \& Ward, E. (2012). Cancer statistics. CA Cancer J. Clin. 60, 277-300.

Kagawa, N., Silber, S. \& Kuwayama, M. (2009). Successful vitrification of bovine and human ovarian tissue. Reprod. Biomed. Online 18, 568-77.

Kim, J.S., Qian, T. \& Lemasters, J.J. (2003). Mitochondrial permeability transition in the switch from necrotic to apoptotic cell death in ischemic rat hepatocytes. Gastroenterology 124, 494-503.

Kim, J.Y. (2012). Control of ovarian primordial follicle activation. Clin. Exp. Reprod. Med. 39, 10-4.

Kim, S.S. (2010). Time to re-think: ovarian tissue transplantation versus whole ovary transplantation. Reprod. Biomed. Online 20, 171-4.

Kim, S.S. (2014). Revisiting the role of heterotopic ovarian transplantation: futility or fertility. Reprod. BioMed. Online 28, 141-5.

Kim, S.S., Hwang, I.T. \& Lee, H.C. (2004). Heterotopic autotransplantation of cryobanked human ovarian tissue as a strategy to restore ovarian function. Fertil. Steril. 82, 930-2.

Kim, S.S., Lee, W.S., Chung, M.K., Lee, H.C., Lee, H.H. \& Hill, D. (2009). Long-term ovarian function and fertility after heterotopic autotransplantation of cryobanked human ovarian tissue: 8-year experience in cancer patients. Fertil. Steril. 91, 2349-54.

Labied, S., Delforge, Y., Munaut, C., Blacher, S., Colige, A., Delcombel, R., Henry, L., Fransolet, M., Jouan,
C., D’Hauterive, S.P., Noël, A., Nisolle, M. \& Foidart, J.M. (2013). Isoform 111 of vascular endothelial growth factor (VEGF111) improves angiogenesis of ovarian tissue xenotransplantation. Transplantation 95, 426-33.

Liu, L.J., Xie, X.Y., Zhang, R.Z., Xu, P., Bujard, H. \& Jun, M. (2008). Reproduction and fertility in wild-type and transgenic mice after orthotopic transplantation of cryopreserved ovaries from 10-d-old mice. Res. Note 37, 353-7.

Lotz, L., Liebenthron, J., Nichols-Burns, S., Montag, M., Hoffmann, I., Beckmann, M.W., van der Ven, H., Töpfer, D. \& Dittrich, R. (2014). Spontaneous antral follicle formation and metaphase II oocyte from a non-stimulated prepubertal ovarian tissue xenotransplant. Reprod. Biol. Endocrinol. 12, 41.

Luyckx, V., Pharm, B., Soares, M., Scalercio, S., Jadoul, P., Amorim, C.A., Soares, M., Donnez, J. \& Dolmans, M.M. (2013). Evaluation of cryopreserved ovarian tissue from prepubertal patients after long-term xenografting and exogenous stimulation. Fertil. Steril. 100, 1350-7.

Martinez-Madrid, B., Donnez, J., Van Eyck, A.S., VeigaLopez, A., Dolmans, M.M. \& Van Langendonckt, A. (2009). Chick embryo chorioallantoic membrane (CAM) model: a useful tool to study short-term transplantation of cryopreserved human ovarian tissue. Fertil. Steril. 91, 28592.

Meirow, D., Baum, M., Yaron, R., Levron, J., Hardan, I., Schiff, E., Nagler, A., Yehuda, D.B., Raanani, H. \& Hourvitz, A. (2007). Ovarian tissue cryopreservation in hematologic malignancy: 10 years' experience. Leuk. Lymphoma 48, 1569-76.

Mhatre, P. \& Mhatre, J. (2006). Orthotopic ovarian transplantreview and 3 surgical techniques. Pediatr. Transplant. 10, 782-7.

Oktay, K., Economos, K., Kan, M., Rucinski, J., Veeck, L. \& Rosenwaks, Z. (2001). Endocrine function and oocyte retrieval after autologous transplantation of ovarian cortical strips to the forearm. JAMA 286, 1490-3.

Parrot, D.M.V. (1960). The fertility of mice with orthotopic ovarian grafts derived from frozen tissue. J. Reprod. Fertil. 1, 230-41.

Paulini, F., Vilela, JM.V., Chiti, M.C., Donnez, J., Jadoul, P., Dolmans, M.M. \& Amorim, C.A. (2016). Survival and growth of human preantral follicles after cryopreservation of ovarian tissue, follicles isolation and short-term xenografting. Reprod. BioMed. Online 33, 425-32.

Prochazka, M., Gaskins, H.R., Shultz, L.D. \& Leiter, E.H. (1992). The non-obese diabetic scid mouse: model for spontaneous thymomagenesis associated with immunodeficiency. Immunology 88, 3290-4.

Revel, A., Laufer, N., Ben Meir, A., Lebovich, M. \& Mitrani, E. (2011). Micro organ ovarian transplantation enables pregnancy: a case report. Hum. Reprod. 26, 1097-103.

Revelli, A., Marchino, G., Dolfin, E., Molinari, E., Delle Piane, L., Salvagno, F. \& Benedetto, C. (2013). Live birth after orthotopic grafting of autologous cryopreserved ovarian tissue and spontaneous conception in Italy. Fertil. Steril. 99, 227-30.

Rodriguez-Wallberg, K.A. \& Oktay, K. (2012). Recent advances in oocyte and ovarian tissue cryopreservation 
and transplantation. Best Pract. Res. Clin. Obstet. Gynaecol. 26, 391-405.

Rodriguez-Wallberg, K.A., Karlstr, P.O., Rezapour, M., Castellanos, E., Hreinsson, J., Rasmussen, C., SheikhI, M., Ouvrier, B., Bozoky, B., Olofsson, J.I., Lundqvist, M. \& Hovatta, O. (2015). Full-term newborn after repeated ovarian tissue transplants in a patient treated for Ewing sarcoma by sterilizing pelvic irradiation and chemotherapy. Acta Obstet. Gynecol. Scand. 94, 324-8.

Salle, B., Demirci, B., Franck, M., Rudigoz, R.C., Guerin, J.F. \& Lornage, J. (2002). Normal pregnancies and live births after autograft of frozen-thawed hemi-ovaries into ewes. Fertil. Steril. 77, 403-8.

Salle, B., Demirci, B., Franck, M., Berthollet, C. \& Lornage, J. (2003). Long-term follow-up of cryopreserved hemi-ovary autografts in ewes: pregnancies, births, and histologic assessment. Fertil. Steril. 80, 172-7.

Santos, R.R., Knijn, H.M., Vos, PLA.M., Oei, CH.Y., Loon, T.V., Colenbrander, B., Gadella, B.M., van den Hurk, R. \& Roelen, B.A.J. (2009). Complete follicular development and recovery of ovarian function of frozen-thawed, autotransplanted caprine ovarian cortex. Fertil. Steril. 91, $1455-8$.

Scalercio, S.R., Amorim, C.A., Brito, D.C., Percario, S., Oskam, I.C., Domingues, S.F.S. \& Santos, R.R. (2015). Trolox enhances follicular survival after ovarian tissue autograft in squirrel monkey (Saimiri collinsi). Reprod. Fertil. Dev. [Epub ahead of print]

Schmidt, K.L.T., Ernst, E., Byskov, A.G., Nyboe Andersen, A. \& Yding Andersen, C. (2003). Survival of primordial follicles following prolonged transportation of ovarian tissue prior to cryopreservation. Hum. Reprod. 18, 2654-9.

Schnorr, J., Oehninger, S., Toner, J., Hsiu, J., Lanzendorf, S., Williams, R. \& Hodgen, G. (2002). Functional studies of subcutaneous ovarian transplants in non-human primates: steroidogenesis, endometrial development, ovulation, menstrual patterns and gamete morphology. Hum. Reprod. 17, 612-9.

Schubert, B., Canis, M., Darcha, C., Artonne, C., Smitz, J. \& Grizard, G. (2008). Follicular growth and estradiol follow-up after subcutaneous xenografting of fresh and cryopreserved human ovarian tissue. Fertil. Steril. 89, 1787-94.

Scott, J.R., Hendrickson, M., Lash, S. \& Shelby, J. (1987). Pregnancy after tubo ovarian transplantation. Obstet. Gynecol. 70, 229-234.

Shultz, L.D., Ishikawa, F. \& Greiner, D.L. (2007). Humanized mice in translational biomedical research. Nat. Rev. Immunol. 7, 118-30.

Silber, S.J. (2012). Ovary cryopreservation and transplantation for fertility preservation. Mol. Hum. Reprod. 18, 59-67.

Silber, S.J. (2016). Ovarian tissue cryopreservation and transplantation: scientific implications. J. Assist. Reprod. Genet. 33, 1595-1603.

Silber, S.J., Lenahan, K.M., Levine, D.J., Pineda, J.A., Gorman, K.S., Friez, M.J., Crawford, E.C. \& Gosden, R.G. (2005). Ovarian transplantation between monozygotic twins discordant for premature ovarian failure. New Engl. J. Med. 353, 58-63.

Silber, S.J., De Rosa, M., Pineda, J., Lenahan, K., Grenia, D., Gorman, K. \& Gosden, R.G. (2008). A series of monozygotic twins discordant for ovarian failure: ovary transplantation (cortical versus microvascular) and cryopreservation. Hum. Reprod. 23, 1531-57.

Sonmezer, M. \& Oktay, K. (2010). Orthotopic and heterotopic ovarian tissue transplantation. Best Prac. Res. Clin. Obstet. Gynaecol. 24, 113-26.

Stern, C.J., Toledo, M.G., Hale, L.G., Gook, D.A. \& Edgar, D.H. (2011). The first Australian experience of heterotopic grafting of cryopreserved ovarian tissue: evidence of establishment of normal ovarian function. Aust. NZ J. Obstet. Gynecol. 51, 268-75.

Stern, C.J., Gook, D., Hale, L.G., Agresta, F., Oldham, J., Rozen, G. \& Jobling, T. (2013). First reported clinical pregnancy following heterotopic grafting of cryopreserved ovarian tissue in a woman after a bilateral oophorectomy. Hum. Reprod. 28, 2996-9.

Stoop, D., Cobo, A. \& Silber, S. (2014). Fertility preservation for age-related fertility decline. Lancet 384, 1311-9.

Suzuki, N., Hashimoto, S., Igarashi, S., Yamanaka, M., Yamochi, T., Takenoshita, M., Hosoi, Y., Morimoto, Y. \& Ishizuka, B. (2012). Assessment of long-term function of heterotopic transplants of vitrified ovarian tissue in cynomolgus monkeys. Hum. Reprod. 27, 2420-9.

Van Eyck, A.S., Jordan, B.F., Gallez, B., Heilier, J.F., Van Langendonckt, A. \& Donnez, J. (2009). Electron paramagnetic resonance as a tool to evaluate human ovarian tissue reoxygenation after xenografting. Fertil. Steril. 92, 374-81.

Van Langendonckt, A., Romeu, L., Ambroise, J., Amorim, C.A., Bearzatto, B., Gala, J.L., Donnez, J. \& Dolmans, M.M. (2014). Gene expression in human ovarian tissue after xenografting. Mol. Hum. Reprod. 20, 514-25.

Vollmar, B., Glasz, J., Menger, M.D. \& Messmer, K. (1995). Leukocytes contribute to hepatic ischemia/ reperfusion injury via intercellular adhesion molecule-1-mediated venular adherence. Surgery 117, 195-200.

Wang, Y., Chang, Q., Sun, J., Dang, L., Ma, W., Hei, C., Shen, X., Zhao, C., Cai, Y., Pei, X., Zhang, X. \& Jiang, X. (2012). Effects of HMG on revascularization and follicular survival in heterotopic autotransplants of mouse ovarian tissue. Reprod. BioMed. Online 24, 646-53.

Wang, L., Ying, Y.F., Ouyang, Y.L., Wang, J.F. \& Xu, J. (2013). VEGF and bFGF increase survival of xenografted human ovarian tissue in an experimental rabbit model. J. Assist. Reprod. Genet. 30, 1301-11.

Yang, H.Y., Cox, S.L., Jenkin, G., Findlay, J., Trounson, A. \& Shaw, J. (2006). Graft site and gonadotrophin stimulation influences the number and quality of oocytes from murine ovarian tissue grafts. Reproduction 131, 851-9.

Yi-Hsin, L., Yu-Chi, Y., Chii-Ruey, T., Wei-Jen, S., Jah-Yao, L. \& Chi-Huang, C. (2011). Evaluating the effects of immunosuppression by in-vivo bioluminescence imaging after allotransplantation of ovarian grafts. Reprod. BioMed. Online 22, 220-7.

Youm, H.W., Lee, J.R., Lee, J., Jee, B.C., Suh, C.S. \& Kim, SH. (2015). Transplantation of mouse ovarian tissue: comparison of the transplantation sites. Theriogenology 83, 854-61.

Zelinski, M.B., Murphy, M.K., Lawson, M.S., Jurisicova, A., Pau, KY.F., Toscano, N.P., Jacob, D.S., Fanton, J.K., Casper, 
R.F., Dertinger, S.D. \& Tilly, J.L. (2011). In-vivo delivery of FTY720 prevents radiation-induced ovarian failure and infertility in adult female non-human primates. Fertil. Steril. 95, 1440-5.

Zhang, H., Yang, Y., Ma, W., Wu, H., Zheng, X., Hei, C., Sun, M., Ma, W.M..H., Chang, Q., Wang, H., Cai, Y., Xie, Y., Zhao, C., Pei, X. \& Wang, Y. (2016). The revascularization and follicular survival of mouse ovarian grafts treated with fsh during cryopreservation by vitrification. CryoLetters 37, 88-102.
Zhang, J.M., Sheng, Y., Cao, Y.Z., Wang, H.Y. \& Chen, Z.J. (2011). Cryopreservation of whole ovaries with vascular pedicles: vitrification or conventional freezing? J. Assist. Reprod. Genet. 28, 445-52.

Zhang, Q., Wang, S.M., Yao, P.B., Zhang, L., Zhang, Y.J., Chen, R.X., Fu, Y. \& Zhang, J.M. (2015). Effects of L-carnitine on follicular survival and graft function following autotransplantation of cryopreservedthawed ovarian tissues. Cryobiology 71, 13540 . 